\title{
Analysis of Capital Market Dual Listing in ASEAN Countries
}

\author{
Kevin Situmorang $^{1 *}$, Budiharto ${ }^{1}$, Paramita Prananingtyas ${ }^{1}$ \\ $\left\{\right.$ kevinsitumorang11@gmail.com ${ }^{* 1}$, budiharto@live.undip.ac.id ${ }^{2}$ pptyas@live.undip.ac.id $\left.{ }^{3}\right\}$
}

Fakultas Hukum, Universitas Diponegoro, Jl. Prof. H. Soedarto, S.H., Semarang, Indonesia $50275^{1}$

\begin{abstract}
The capital market is an alternative source of corporate finance, so this encourages companies to sell their shares on the stock exchange. However, with the expansion of the business to the world, sometimes, the companies need more than one stock exchange, including foreign ones. The company than carried out a dual listing, namely listing of shares in to different exchanges. Dual listing has also begun to be carried out by a number of ASEAN countries. This study discusses the application of dual listing in a number of ASEAN countries and the possibility of its application in Indonesia. This study uses a normative juridical approach. The research specification used is analytical descriptive by examining secondary data and data that is delivered via the internet. The data presented is based on inductive thinking methods. Based on the results of the study, several ASEAN countries have implemented a dual listing policy by applying certain classifications to foreign companies with the aim of protecting the interests of shareholders and ensuring corporate governance. Indonesia has tried to implement a dual listing policy, but only applied for the Indonesian Depositary Receipt (SPEI). The dual listing mechanism was not immediately implemented because the capital market regulations did not allow foreign corporate legal entities to carry out dual listings.
\end{abstract}

Keywords: Capital Market, Dual Listing

\section{Introduction}

\subsection{Background}

The progress and prosperity of a country can be seen from its economic development. Economic development can only be realized if the government implements development. In the implementation of a country's national economic development funding is needed from both the government and the community. One form of financing is through financing business activities. Financing of share activities can be done through capital market activities.

The term "Capital Market" is used as a translation of the term "Capital Market", which means a place or system on how to meet the needs of funds for capital of a company, and also a market where people buy and sell securities that have just been issued. According to Law No. 8 of 1995 concerning the Capital Market,[1] the Capital Market is an activity concerned with public offering and trading of securities, public companies related to the issuance of securities, and professional institutions related to securities. The capital market is similar to markets in general, because the capital market also gathers people to trade. For example by buying and selling. In the capital market, what is traded is securities. The capital market is 
defined as a market where long-term funds, both debt and equity, are traded. Long-term funds which constitute their own capital are usually in the form of shares.

The capital market is one alternative source of financing for both the government and the private sector. Governments that need funds can issue bonds or debt securities and sell them to the public through the capital market. Likewise, the private sector, which in this case is a company that needs funds can issue securities, both in the form of shares and bonds and sell them to the public through the capital market.

The capital market provides a longer-term source of financing, which is invested as capital to create and expand employment that will increase the volume of healthy and profitable economic activity. The capital can be in the form of production funds or funds for the procurement of capital goods such as goods, factories and equipment that are actually used to produce goods and services.

Given that the capital market is one alternative source of corporate finance, companies are encouraged to sell their shares on the stock exchange. However, with the expansion of the business world, the companies sometimes need more than one stock exchange, and even foreign stock exchanges are also needed. So it is very possible to need more than one stock exchange in more than one stock exchange, even foreign stock exchanges are also needed. So it is possible to need more than one stock exchange in more than one foreign country, for example in an Initial Public Offering (IPO) of a local company that wants to offer its shares to parties in other countries. In this regard, the history of the capital market shows that the attachment and boundaries of the state territory are often the cause of many companies from being able to use and obtain funds from other countries, where the company is not established or does not operate in carrying out its business activities. This area limitation also causes many domestic investors of a country in general to have difficulty in investing (in the form of portfolio diversification) on exchanges in their country and in foreign securities which are considered good enough as one or more investment portfolios. This is usually due to obstacles related to procedural, and legal rules, the provisions of other countries' capital markets that must be met, and the relationship with relevant authorities, which must be carried out by the company and related to the registration process and trading of securities to be offered on exchanges in other countries.

Efforts to sell shares on the stock exchange abroad can be done through the Dual Listing policy, which is an activity carried out by a company to register and trade its shares not only in one capital market but also sell its shares in another different capital market. The dual listing effort is quite common, both in stock exchanges in the Americas, Europe and Asia. On the American stock exchange (NYSE), dual listings are regulated under The Securities Act of 1933, The Securities Exchange Act of 1934 and The NASD Rules. The dual listing policy is also developing in a number of ASEAN countries. This development was marked by the establishment of the ASEAN Capital Market Forum in 2008. The ASEAN Capital Market Forum (ACMF) is an ASEAN capital market regulator forum aimed at achieving harmony between the capital markets in the ASEAN region. One of ACMF's latest achievements is the agreement between the Singapore Capital Market, the Malaysian Capital Market and the Thai Capital Market to implement the ASEAN Disclosure Standard. The implementation of the ASEAN Disclosure Standard causes the dual listing policy to be carried out by all capital market players in Singapore, Malaysia and Thailand. In this agreement, capital market investors in the three countries can transact shares with issuers across countries without any regulatory and political policy restrictions. In Indonesia, the Dual Listing policy is implemented indirectly by using the Indonesian Depositary Receipt or SPEI as stipulated in Bapepam Regulation No.IX.A.10 regarding the Public Offering of Indonesian Depositary 
Receipts. However, Indonesia currently does not have a Dual Listing policy arrangement that is implemented directly like that of Malaysia, Singapore and Thailand. Seeing this condition, it is interesting to study how the further implementation of the dual listing policy in ASEAN countries and how it might be applied in Indonesia. This topic will then be discussed in the form of a thesis entitled "Analysis of Dual Listing Critical Market Capital Countries in Asean."

\subsection{Formulation of the problem}

Based on the background that has been described, the formulation of the problem in this study is as follows:

1. How does the application of Dual Listing work in ASEAN countries?

2. What are the obstacles in implementing Dual Listing in the Indonesian capital market?

\section{Method}

The method of approach used in this study is the normative juridical approach. The method of normative juridical approach means a study that seeks to synchronize the provisions of the applicable law with the rules that apply in the legal protection of norms or other legal regulations with relation to the legal regulations in actual practice in the field.[2] The use of this method is carried out considering that the research conducted refers more to the laws and regulations, namely the relationship between one arrangement with other arrangements and the relationship with application in practice. The juridical aspect in this research is a study based on the science of commercial law which is about capital market law which specifically covers dual listing policies and legislation relating to the problem under study.

The specifications of this study use descriptive analytical research specifications. In this study illustrates the dual listing policy that will be analyzed using theories, science and the writer's own opinion which will get a conclusion.

The data used are secondary data. Secondary data is data obtained from library materials using primary and secondary legal materials. [3]

The method of data collection is based on the source of the data obtained in this study. The data is collected by means of library research, which consists of primary legal materials, and secondary legal materials as well as prior research related to the object in the form of legislation laws, literature and other scientific papers.

All data that has been collected is then processed and analyzed using qualitative methods. Qualitative analysis, which describes the picture of the data obtained and connects with each other to get a general conclusion. [4] The data that have been analyzed qualitatively, in this case the relationship between theories obtained from library studies will be analyzed and reviewed and then systematized into data analysis compiled in the form of legal writing. 


\section{Results and Discussion}

This Word document can be used as a template for journal. This Word document can be used as a template for journal. This Word document can be used as a template for journal. This Word document can be used as a template for journal.

\subsection{Implementation of dual listing in ASEAN Countries}

\subsubsection{Singapore}

SGX-ST has two registration boards, namely Main Board and Catalyst Board. Listing on the Main Board can be either a primary listing or a secondary listing. The Dual Listing in SGX is called the Secondary Listing. Secondary listings can only be done on the Main Board. Foreign companies must first meet the general listing requirements on the Main Board (The SGX Main Board listing requirements) regulated in the SGX-ST Listing Manual before fulfilling the specific rules of the secondary listing. After fulfilling the general requirements, they must fulfill certain rules for Secondary listings.

First, the original Exchange where the issuer conducts a primary listing (Home Exchange) will fully enforce the listing rules on the company. The second exchange on which the company is listed (Host Exchange) generally will instead depend on the Home Exchange to regulate the company. The role of the main regulator and supervision is in the hands of regulators who are in the jurisdiction of the Home Exchange (Home Jurisdiction).[5] SGX, as the Exchange Host, relies on regulators from Home Exchange to manage Home Exchange rules and maintain Home Exchange regulatory standards.

Second, there are different regulations that apply to each company based on the classification of the jurisdiction of the country of origin (home jurisdiction) of the company. This classification distinguishes whether the jurisdiction of the company that wants to do a secondary listing on SGX is included in the "Developed Markets" or "Developing Markets."

Companies that originate from the Developed Market and have complied with the SGX Admission Standards do not need to get a full review from SGX on the legal and regulatory framework contained in Home Jurisdiction and can conduct secondary listings on SGX by only meeting the following conditions: [5]

1) Subject to Rule 217 SGX Listing Manual.

2) Subject to Rule 751 SGX Listing Manual.

3) The company does not need to fulfill the continuing listing obligations provisions contained in the SGX Listing Manual.

For the companies originating from the Developing Market, SGX will identify and conduct a full review of the legal and regulatory requirements of the Home Exchange to identify areas related to shareholder protection and corporate governance that have the potential for improvement. Companies originating from Developing Markets will be requested by SGX to fulfill Rule 217, Rule 751, continuing listing obligations from Chapter 9, Chapter 10 and Chapter 13 of SGX Listing Manual.[4] If SGX assesses fields related to interested person transactions, acquisitions and realizations, and delisting, it requires an increase.

\subsubsection{Malaysia}

The company can register in two types of Bursa Malaysia markets, namely Main Market and ACE Market. Foreign companies can only register on the Main Market. Recording can be 
done through Primary listings or Secondary listings. Foreign companies wishing to register on the Bursa Malaysia must be incorporated in jurisdictions subject to company law and other relevant laws and regulations, which have standards at least equivalent to those in Malaysia, specifically related to corporate governance, shareholder protection and minority interests, and takeover and merger regulations.[6] Domestic companies or foreign companies that want to do primary listings on the Malaysian stock exchange must meet the quantitative criteria, qualitative criteria, and additional criteria that must be met by foreign companies who want to search for primary listings. [7] On the other hand, foreign companies that want to conduct secondary listings on the Bursa Malaysia only need to meet certain qualitative criteria, additional criteria (additional criteria) and do not need to meet quantitative criteria. [8]

\subsubsection{Thailand}

Foreign companies must get approval from the Thai SEC to offer their shares to public investors in Thailand, and approval from the SET Board of Governors to register their shares in the SET. Foreign companies must comply with specified approval criteria, disclosure standards and other relevant regulations in a manner similar to those applicable to Thai companies, such as shareholder protection, prevention of conflict of interest and adequate information disclosure.[9] Foreign companies must comply with certain criteria to conduct secondary listings. Secondary criteria considerations for foreign companies are divided into two types of classification, namely whether the country of origin of the company is classified as a Recognized Country or Unrecognized Country. [10]

\subsubsection{Analysis of the dual listing process of countries in ASEAN}

When the Capital Market Authority of a country opens an opportunity for foreign companies to do dual listing on their bursas, the next problem is how to overcome differences in capital market regulations owned by the country of origin of foreign issuers with capital market regulations provided by the country where the dual listing is conducted. Each country certainly has its own specificities in its regulations, from the legal system, corporate law, and capital market law that is adjusted to the conditions and capabilities of the current stock exchange. These regulatory differences can become obstacles for the dual listing to take place, bearing in mind that the laws of each country have their own level of complexity. It takes a kind of standardization of rules to bridge the differences in rules that become obstacles in implementing this dual listing. ASEAN countries such as Singapore and Thailand use the classification provided by the FTSE and MSCI index providers to determine whether the country of origin of a foreign issuer (Home Jurisdiction) has rules that are equivalent to the country where the dual listing is implemented (Home Exchange). This classification is a reference for SGX (Singapore Exchange) and SET (Stock Exchange of Thailand) to determine the regulatory framework that will be applied to a foreign issuer who wants to do a dual listing in their country.

The Financial Times Stock Exchange (FTSE) and Morgan Stanley Capital International (MSCI) are the two leading providers of data and leading international economic indices that determine market classification in a number of countries. FTSE and MSCI determine the country classification into Developed Market and Developing Market (Advanced Emerging, Secondary Emerging or Frontier). The classification is determined based on economic size, wealth, market quality, market depth, and breadth of a country's market.[5]

Capital market regulators in Singapore, Thailand and Malaysia apply high standards of corporate governance and shareholder protection for foreign companies that want to conduct dual listings with the aim that the interests of shareholders obtain legal protection and capital 
market quality can be maintained. The market classification in Singapore and Thailand also aims to protect the interests of investors, because based on the results of this classification, companies originating from the Developed Market are considered to have an established and mature legal and regulatory regime which can then offer a level of shareholder protection and corporate governance standards. tall one.

\subsection{Possible application of dual listing in Indonesia}

\subsubsection{Constraints on the implementation of dual listing in Indonesia}

At present, foreign companies wishing to record secondary listings in Indonesia can only go through the Indonesian Depositary Receipt mechanism (SPEI).

In Indonesia, the Depositary Receipt is called the Indonesian Depositary Receipt or SPEI. The issuance of foreign shares in Indonesia in a modern way, especially those done through the issuance of Indonesian Depositary Receipt, is still relatively new in Indonesia. The issuance of Indonesian Depositary Receipts was only introduced in Indonesia after the issuance of regulations in the form of Bapepam Chairman's Decree No. Kep-49/PM/1997, dated December 26, 1997, which is well known for Rule Number IX.A.10 regarding the Indonesian Depositary Receipt. Bapepam Regulation Number IX.A.10 regarding the Public Offering of Indonesian Depositary Receipt (IDR) allows the main effects not only to be offered abroad, but also to securities offered domestically by local issuers. When the task of supervising the capital market financial industry officially shifted from Bapepam-LK to the OJK in 2012, the process of developing rules regarding the listing of multiple shares (dual listing) as stipulated in the application of the Indonesian Depositary Receipts (SPEI) was recognized as having a number of obstacles. IDX's Managing Director for the 2012-2015 period, Ito Warsito revealed that the desire of foreign companies to list on the Indonesia Stock Exchange was hampered by the regulation of the Financial Services Authority (OJK) which has been vacuum since 2009.[11] Bearing this in mind, until now there has not been a single foreign company that has listed shares on the Indonesia Stock Exchange. [12] Some of the obstacles found in Indonesia's capital market regulations are as follows:

1) The SPEI mechanism is deemed unattractive for foreign companies because it cannot register shares directly, and instead must use an intermediary from the Custodian Bank.

2) Companies that want to register must have a legal entity PT.

3) Capital market investment prospectus must be prepared and signed by the Capital Market Supporting Professionals registered with OJK.

\subsubsection{Analysis of constraints on the implementation of dual listings in Indonesia}

At the very least, Indonesian capital market law regulates several types of securities to be listed on the Indonesia Stock Exchange, such as stocks and bonds. For foreign companies, the possibility to conduct a public offering of shares on the Indonesia Stock Exchange can only be done by using the Indonesian Depositary Receipt Certificate mechanism. This means that foreign companies cannot register shares directly. While the possibility of listing shares directly through a public offering of shares (going public) on the Indonesia Stock Exchange still faces a number of obstacles. Both of these possibilities have not yet been tried by Foreign Companies because there are still a number of obstacles.

The main problem for foreign issuers in meeting these requirements is a requirement that only Legal Entities in the form of Limited Liability Companies (PT) can do the listing on the Indonesia Stock Exchange.[7] This provision is very deterring foreign issuers because they 
already have their own legal entities in accordance with the jurisdiction of their respective countries. This means that foreign issuers cannot register on the Indonesia Stock Exchange while they are still using their original legal entity, and must form a limited liability company. If a foreign issuer must establish a PT in order to be listed on the exchange, this provision cannot be called a dual listing provision, where the dual listing provision means the condition where the issuer is listing on two different exchanges with an existing legal entity. As long as Indonesian Capital Market regulations still require issuers to have a limited liability company, foreign issuers cannot do a dual listing on the Indonesia Stock Exchange.

In addition, this PT Legal Entity requirement also has other obstacles, where PT Law in Indonesia also has Corporate Governance provisions that are not necessarily equivalent to Corporate Governance standards in other countries, so certain adjustments must be made to avoid differences in Corporate Governance standards.

Reflecting the dual listing regulations in Singapore, there are provisions regarding the classification of countries based on their original jurisdiction, namely the classification of Developed Market and Developing Market.[5] The reason SGX applies this provision is that based on the results of the FTSE and MSCI classification. The legal and regulatory regimes in Developing Markets countries may not offer adequate guarantees of the level of shareholder protection and corporate governance standards available in the country. Accordingly, SGX considers it is necessary to increase through the imposition of additional continuing listing obligations to companies from Developing Markets countries, with the aim of protecting the interests of investors. [7]

If re-linked with the provisions of Secondary listing in Singapore, the application of the principles of Corporate Governance in Indonesia has not yet reached the point where Indonesia has capital market regulations that are equivalent to countries included in the Developed Market. Based on the latest FTSE and MSCI indexes, Indonesia is still categorized as a Developing Market country. Based on the FTSE Equity Country Classification September 2019 Annual Announcement, Indonesia is still categorized as Secondary Emerging, [13] whereas based on The MSCI 2019 Global Market Accessibility Review, Indonesia is still classified as an Emerging Market.[14] The results of this classification indicate that the quality of the Indonesian capital market is not as good as the quality of the capital markets of countries that are in the developed market. These results also indicate the need to improve the quality of Indonesian regulations so that they are fully prepared to effectively implement the dual listing policy.

\section{Conclusion and Suggestion}

\subsection{Conclusion}

1. Implementation of Dual Listing in ASEAN Countries such as Singapore, Malaysia and Thailand is carried out under the name Secondary Listing. Secondary Listing Policy focuses on the situation where a company already has a primary listing in a country (Home Exchange), but at the same time, the company intends to do a secondary listing on another country's stock exchange (Host Exchange), so that the company is listed in two different countries. The Secondary Listing approach implemented by Singapore, Malaysia and Thailand aims to provide adequate guarantees to the provisions of shareholder protection and corporate governance, 
because these guarantees are needed to protect the interests of capital market investors.

2. The current application of Dual Listing in Indonesia can only be done indirectly by using the Indonesian Depository Receipt (IDR) mechanism. However, the SPEI provisions have problems because the SPEI mechanism is considered quite complicated for a number of foreign companies. SPEI must be entrusted to the Custodian Bank as an intermediary so that the safekeeping mechanism is deemed unattractive to foreign companies because companies prefer to register their shares directly without going through intermediaries. The mechanism for direct listing of shares through a public offering of shares also has a number of obstacles because Indonesian regulations so far have not allowed foreign companies to conduct stock listing. In addition, the Company's Prospectus must also be prepared and signed by the Capital Market Supporting Professionals registered with OJK. This also becomes another obstacle because foreign companies must make sure before making a prospectus that is prepared and signed by the capital market supporting profession from other countries that are not registered in the FSA, so it is not possible to use the prospectus to be offered in Indonesia.

\subsection{Suggestion}

Based on the results of the study, the following suggestions can be submitted:

1) The Government, in this case, the Financial Services Authority (OJK) and the Indonesia Stock Exchange (IDX) must continue to work together in improving the quality of the Indonesian capital market. So, they can compete with the stock exchanges in other countries, especially in the ASEAN countries' stock exchanges that have implemented dual listings such as The Singapore Exchange Securities Trading Limited (SGX-ST), Bursa Malaysia, and The Stock Exchange of Thailand (SET). Until now, the Indonesian Capital Market is still classified as a developing market by FTSE and MSCI. A number of efforts are needed to improve the status of Indonesia as a developed market. Bearing in mind the quality of the capital market of a developed market country is considered more attractive for foreign companies that have plans to conduct dual listings.

2) Harmonization of Indonesian capital market regulations needs to be carried out as soon as possible considering that in addition to the quality of the capital market, differences in regulations are also a major obstacle for foreign companies intending to carry out dual listings. Indonesian capital market regulations must provide facilities for foreign companies, because the Government is also trying to encourage a number of companies to conduct dual listings in Indonesia. The revision of the Capital Market Law must also immediately enter the National Legislation Program (Prolegnas) in order to catch up with the capital market regulations of other countries. 


\section{References}

[1] Law Number 8 of 1995 concerning Capital Markets. .

[2] A. Suharsimi, Prosedur penelitian suatu pendekatan praktik. Jakarta: Rineka Cipta, 2006.

[3] S. Soekanto, S., and Mamudji, Penelitian hukum normatif: Suatu tinjauan singkat. Jakarta: Raja Grafindo Persada, 2001.

[4] R. H. Soemitro, Metode Penelitian Hukum. Jakarta: Ghalia Indonesia, 1982.

[5] SGX, Regulatory Framework for Secondary Listings Consultation Paper. Singapore, 2014.

[6] Equity Guidelines, Paragraphs 5.38.

[7] B. McKenzie, Cross-Border Listings Handbook, 7thd. 2017.

[8] Bursa Malaysia, "List of Companies." [Online]. Available: http://www.bursamalaysia.com/market/listed-companies/listing-on-bursamalaysia/listing-criteria.

[9] T. Pootranon, P., Tantirangsi, N., and Ratanachand, The Initial Public Offerings Law Review 2018. Thailand: Weerawong C\&P, 2018.

[10] SET, A guide to Secondary Listing. Thailand: SET, 2017.

[11] T. Hadiyantono, “Asing sulit masuk BEI karena aturan OJK belum ada." [Online]. Available: https://investasi.kontan.co.id/news/asing-sulit-masuk-bei-karena-aturanojk-belum-ada.

[12] I. D. Santoso, "Initial Public Offerings 2020: Indonesia. Global Legal Insights (GLI)," $21 \mathrm{Apr}$ 2020. [Online]. Available: https://www.globallegalinsights.com/practiceareas/initial-public-offerings-laws-and-regulations/indonesia\#chaptercontent6.

[13] FTSE Russell, "FTSE equity country classification process," Mar 2019. [Online]. Available:

https://www.ftse.com/products/downloads/FTSE_Equity_Country_Classification_Pap er.pdf.

[14] MSCI, “MSCI Global Market Accessbility Review,” Jun 2019. [Online]. Available: https://www.msci.com/documents/1296102/1330218/MSCI_Global_Market_Accessib ilty_Review_June_2019.pdf/511b8357-58a5-4992-3774-47f60baa1505. 